Research Article

\title{
The Influence of Information Interaction Behavior on Value Co-Creation Business Model of Online Education Enterprises Performances from the Perspective of Supply Chain
}

\author{
Jingjing Lv, ${ }^{1}$ Nan Wang $\mathbb{D}^{1},{ }^{1}$ and Shaoxin Xiang ${ }^{2}$ \\ ${ }^{1}$ School of Economics, Guangdong Ocean University, Zhanjiang, Guangdong 524088, China \\ ${ }^{2}$ Yunnan Normal University, Kunming, Yunnan 650500, China \\ Correspondence should be addressed to Nan Wang; wang1023nan@gdou.edu.cn
}

Received 26 October 2021; Accepted 29 November 2021; Published 17 December 2021

Academic Editor: Punit Gupta

Copyright (c) 2021 Jingjing Lv et al. This is an open access article distributed under the Creative Commons Attribution License, which permits unrestricted use, distribution, and reproduction in any medium, provided the original work is properly cited.

\begin{abstract}
This paper analyzes the impact of information interaction ability on the value co-creation business model of online education enterprises from the perspective of supply chain. Integrate the perspective of supply chain and summarize the content of supply chain capability and performance. This paper analyzes the connotation and shortcomings of information interaction ability, combines the connotation of value co-creation to maximize the advantages of information interaction, assumes the impact of information interaction on value cocreation through questionnaire survey method, uses software to analyze the reliability and validity of data, and proves that the data are reasonable. Information interaction has a positive impact on the value co-creation business model of online education enterprises.
\end{abstract}

\section{Introduction}

Online education enterprise is a new teaching mode booming in the past two years. Under the current Internet environment and market economy environment, it has great development space. Although online education is mainly for the convenience of students to receive education at home, it is still a commercial organization with profit as the ultimate goal in the final analysis. Under the current business model, if an online education platform wants to be long term, it is necessary to create commercial value [1-3]. At present, online education in China is still in the initial stage. In order to attract more customers to accept online education, many enterprises have reduced their interests to the minimum, and more business value has not been highlighted. In order to achieve value co-creation, online education enterprises are also trying to explore and develop a value co-creation business model. For online education enterprises, the use of a co-creation value model can help enterprises create effective value [4]. At present, online education enterprises are facing the competitive pressure of huge student groups and schoolwork. Under the fierce competition market environment, independent online education enterprises cannot occupy the dominant market [5]. Only by information interaction, sharing industry information, and market situation can they achieve a win-win situation. Establishing and deepening the information exchange ability between online education enterprises and reducing the information isolation between enterprises can change the confusion encountered by enterprises in independent operation (there is a certain resource information dependence between online enterprises, and the information interaction ability can enhance their symbiosis) and solve the work content that enterprises cannot complete in independent operation [6]. Under the market economy, the competition among the same enterprises is becoming more and more fierce, and the related enterprises are gradually aware of this situation and are more willing to strengthen contact and share industry information with the enterprises of the same level and the same business model [7-9].

The supply chain is a network chain structure formed in the process of commodity circulation, aiming at the final receiving of goods by users. Some famous experts have expounded in their own works the fact that in today's market economy, enterprises are no longer the main body, but the supply chain is the main body. In the whole market, 
the competition among enterprises is no longer the competition to seize the market, but the competition between supply chains [10]. It can be seen that in the current situation of the increasing shortage of resources, the competition of supply capacity reflects the competition of the supply chain, and the results of supply competition are presented through the results of supply chain performance. From the perspective of the supply chain, this paper studies the evolution and development of the value co-creation business model of online education enterprises under the influence of information interaction ability and takes actual enterprises as the research object to carry out the case study.

\section{Basic Concepts of Supply Chain}

\subsection{Integration from the Perspective of Supply Chain}

2.1.1. The Meaning of Supply Chain Integration. The whole process of a product from production to sales involves many aspects of interest, among which the main roles include the producer responsible for the realization of the product, the supplier responsible for providing raw materials, the distributor responsible for the large-scale sales of goods, and the retail retailer responsible for the small-scale sales of goods. It is these businessmen who play different roles that form a closely linked and comprehensive economic network to realize the overall operation of the supply chain. Ordering, production, and transaction are all important parts of supply chain operation [11].

The fundamental purpose of online education enterprises using a supply chain is to ensure that they can not only obtain profits but also meet the basic needs of consumers. Only by meeting the needs of consumers can enterprises obtain the profit in the target. The fundamental operation purpose of each link in the supply chain is to meet the needs of consumers. Although the seller, supplier, and manufacturer are the key components, if subdivided, it also includes the most critical consumer, warehousing, transportation, and other branches. Consumers are the most critical link in the whole supply chain. It is precise because consumers have a demand for goods that drives the reasonable operation of the supply chain. From this level, it can be said that consumers are the inexhaustible power to drive the supply chain from one end to the other. Consumers send out their own demand for goods, and suppliers and manufacturers receive such requests, making production behavior, and the transportation department should give full play to the convenience of transportation, realize the supply of goods to consumers through retailers or distributors, and improve the bottom-up supply chain structure.

2.1.2. Supply Chain Integration. The integration of supply chain content can be divided into two parts, namely, external and internal integration. For the internal integration of the supply chain, it mainly focuses on the internal activities of online education enterprises, in order to achieve significant cooperation between suppliers and enterprises, and at the same time, online education enterprises meet the needs of consumers, coordinate and synchronize the activities of different departments in the enterprise; the external integration of online education enterprises is to build an alliance between external partners and online education enterprises, realize the common business strategic objectives of several enterprises, unify and coordinate the business operation process and cooperative operation process of each enterprise, and realize the unity of cooperation strategy. It is through this internal and external supply chain integration to improve the upper and lower ends of the supply chain management process and business model, and effectively improve the business performance of enterprises.

The purpose of integrating the supply chain is to improve the strategic cooperation ability and information sharing ability of online education enterprises in the operation stage. After the adjustment, the enterprises in each link of the supply chain cooperate with each other for common interests and operation purposes and work together for the strategic goal, so we should strengthen the deep cooperation of similar online education enterprises. At the same time, the deep integration of online education enterprise's supply chain is also to integrate and strengthen the internal and external business processes. Through the integration of the supply chain, the interests of the cooperative online education enterprises are maximized to enhance the value of each enterprise.

Through the above analysis, it can be seen that each node in the supply chain realizes the top-down integrated connection through the integration and adjustment of the supply chain. Through the integration and optimization of the supply chain, it realizes the closely connected supply chain structure, ensures that each associated enterprise can add value in the connection of the whole supply chain, obtains effective income, and, to a certain extent, ensures the close connection between production and consumption, so as to achieve the goal of all in one service. This kind of supply chain adjustment improves the overall economic benefits and soft power of enterprises, promotes the overall development of affiliated enterprises, and also improves China's comprehensive soft power to a certain extent.

\subsection{Capability and Performance of Supply Chain.} Logistics circulation ability and managers' decision-making ability and management ability in the process of supply chain operation are the embodiment of supply chain ability. In previous studies, it has been found that when defining the internal capability of the supply chain, the concept is composed of multiple dimensions, and this multidimensional problem is also involved in the above supply chain integration. As long as it includes production, storage, transportation, sales, and other links, these links together constitute the overall process of the supply chain, and the process also includes two levels of supply chain capabilities [12]. One of them is the basic ability of the supply chain; that is, the enterprise at each end of the supply chain completes the part of the work that the enterprise needs to be responsible for according to its own work content and division of labor content. Every link of the enterprise is concerned 
about the goal of profit as the goal; the main work is to ensure that the enterprise can work normally, so the basic ability of the supply chain is the ability of the basic work of the supply chain. The ability of the second level is the service ability that the supply chain can carry. This level needs the supply chain to have higher ability. The so-called service ability is the ability that each enterprise in each link of the supply chain can make the best response in the increasingly fierce market economy. The actual operation is more difficult, so once it starts, it will become a unique ability $[13,14]$. The availability of these two levels of capabilities reflects the management of supply chain operation, which is related to the performance of supply chain operation.

Although the management and operation process of the supply chain is clear, it is an extremely complex process to form a complete and effective supply chain. Therefore, it is necessary to evaluate the operation performance of the supply chain. The relationship between the supply chain and the enterprise is both exterior and interior, and also, they affect each other. It has a strong guiding role to obtain the evaluation and analysis results between the enterprise and the supply chain. When evaluating the performance of the supply chain, it takes the cost, quality, delivery time, and other indicators as the standard, to modify the indicators appropriately according to the actual situation and research needs of the enterprise, and establish an index system to evaluate the performance of the supply chain.

\section{Description of Information Interaction Ability}

By using the mode of information interaction, enterprises can realize the information sharing and knowledge commonality of enterprises at each end of the supply chain, master the user needs and production standards, and have a unified understanding of the laws and regulations related to the production and transportation of related products, so as to promote enterprises to realize value co-creation. If online education enterprises want to develop for a long time, they need effective management and information interaction means to ensure the healthy competition. Information interaction can improve financial performance and supply chain performance and significantly increase user perception and emotional commitment.

One of the advantages of information interaction in promoting enterprise value co-creation is the transformation from information interaction resources to information interaction ability. The detailed process of this transformation ability is shown in Figure 1.

Online education enterprises use new information technology to build information interaction facilities to ensure the smooth and stable operation of online education, so as to improve the interaction efficiency and lay a good foundation for other content of subsequent information interaction; talents with the ability of information interaction constitute the human resource reserve of online education enterprises, bringing advanced technology and work experience to the enterprises. Combined with the current high, refined, and cutting-edge information technology, the enterprise's information interaction resources are formed. It is precisely because of the integration of these different functions that the values of enterprises can be created together.

Researchers in various fields have made preliminary achievements in the research of information interaction, but in the current form, there are still some problems in the research of interactive information.

3.1. The Object of Interaction Is Unknown. The key point of information interaction is the information interaction between enterprises at each end of the supply chain, but this excessive attention ignores the information interaction among information networks (companies at each end of the supply chain), value networks (between customers and enterprises), and customer networks (between customers).

3.2. The Scope of Interaction Is Unknown. Although, simply speaking, the relationship between the enterprises at each end of the supply chain is information interaction, the detailed interaction content is extremely extensive. In addition to the interaction of customer information, information interaction also needs to realize the interaction of production technology, new learning technology, and the interaction between scientific and technological means and users. These interactions are complex and changeable. There are many contents involved, and the boundary is often unclear in practical research [15].

3.3. The Level of Interaction Is Chaotic. At present, the interaction of basic production information and sales information between enterprises is a relatively basic content in the research field, but the most profound and core information is needed to achieve the healthy development of enterprises. In recent years, with the rapid development of cloud technology, Internet technology, and big data technology, a lot of information content can be obtained without going out of the house. This form has changed the traditional way of human communication and the management and distance between people, people and things, and things and things, breaking through the traditional restrictions. There are huge differences between the transmission frequency and privacy of information.

In the actual operation process of enterprises, in addition to the basic way of information interaction, continuous and in-depth information characteristics are all new characteristics of information interaction. It can be seen that the study of information interaction needs to start from the overall perspective of the enterprise. From the current research perspective and from the perspective of supply chain, information interaction is not only a simple technical ability, but also a core ability from the perspective of overall strategy. The application of information interaction in the value cocreation business model of online education enterprises will bring great benefits to the development of enterprises.

This section studies the basic concept of information interaction in detail; that is to say, under the background of 


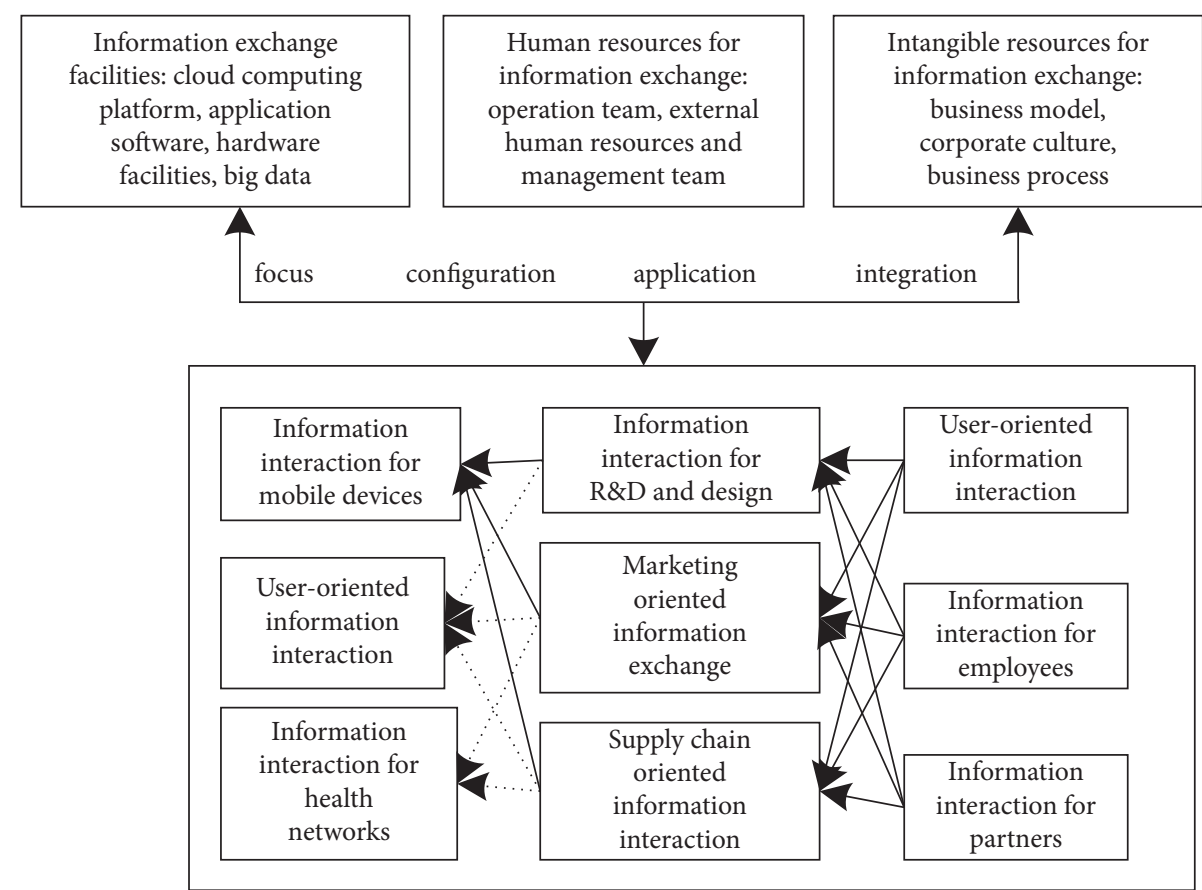

FIgURE 1: The transformation process from information interaction resources to information interaction capabilities.

the new economic environment, enterprises adjust and apply the content of information interaction. The fundamental purpose of interaction is to realize the value of enterprises, co-create business models, and help enterprises gain more competitive advantages in the fierce competitive environment. The communication principle of information interaction is shown in Figure 2.

Information interaction capability includes various concepts. Firstly, information interaction technology can provide more massive information interaction technology to online education enterprises under the rapid development of emerging information technology, so as to build more reasonable information interaction tools, help enterprises obtain more benefits in the business process, lay a favorable foundation for online education enterprises to achieve business value co-creation, and provide a reference for online education enterprises. The competitive development of enterprises brings necessary material resources support [16]. The other is that the guiding goal of information interaction is the value co-creation of enterprises. In recent years, the rapid development of all kinds of new information technology has led to the surplus of information resources in most online education enterprises. When the value cocreation is directly related to the user experience, the advantages of these new information technologies can be brought into full play.

\section{Connotation and Classification of Value Co-Creation Model}

4.1. Connotation of Value Co-Creation Model. Taking the individual as the center is a new means of value creation under the perspective of market economy and supply chain. The creation of this kind of value is no longer solely

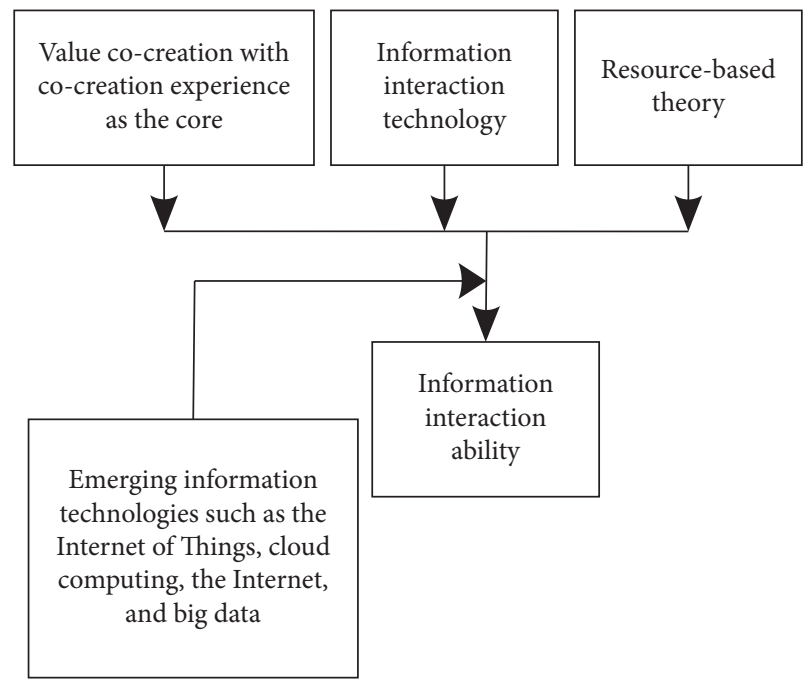

FIgURE 2: Principle of information interaction and transmission.

dependent on the creation of enterprises but needs the joint creation of enterprises and customers. Value cocreation business model and information interaction share the enterprise's work tasks with customers who buy goods. The identity of customers has changed significantly. That is to say, under the same supply chain, customers and suppliers and manufacturers and sellers form a direct connection, which is also one of the links of enterprise value pursuit [17]. Customers not only create their own value, but also help enterprises reduce the consumption of human costs and create more value for enterprises. This proves that, from the perspective of supply chain, co-creation of value is not created by enterprises, but by customers' participation. 
From the perspective of supply chain, enterprises and customers are closely connected in each link. Customers change from passive consumption to active participants in interest activities. There is an interactive and cooperative relationship between them, and the value is created together. In other words, under the information interaction technology, in order to achieve the common goal, customers and enterprises continuously transfer information and exchange their own resources so as to ensure customers' good consumption experience and obtain more information content, realizing the common creation of interests with enterprises. To study the specific performance of this kind of value cocreation is that customers participate in product design, or directly carry out consumer behavior to bring value to enterprise development, which is the most intuitive interaction and value co-creation between the two.

From the above research and analysis, we can see that the cooperation between enterprises and customers is mainly the demand for each other's resources. That is to say, customers need the products produced by enterprises, while enterprises need the demand information of users. Such resources need to cooperate between customers and enterprises under the information interaction technology so as to obtain a lot of information and make rational use of it to maximize benefits. Generally speaking, information interaction is the basis of value co-creation, and value acquisition is the ultimate goal of value creation from both the perspective of customers and enterprises. The key point of value co-creation is to realize the value experience of customers and enterprises. It can be seen that enterprises at each end of the supply chain are not the main body to obtain value, and customer participation is also the key step to realize value cocreation. The closer the relationship between customers and enterprises is, the more harmonious the value can be maximized, and this kind of information interaction runs through all links of the supply chain in every step of every enterprise.

4.2. Value Co-Creation Classification. For value co-creation, previous studies have divided it into two categories in detail, one of which is the value jointly generated by the enterprise and the customer, with the enterprise as the leading and the customer as the cooperator; the other is the value creation method with the enterprise and the customer as the main body, with the customer as the leading, and the enterprise as the cooperator. The following is the specific analysis process.

4.2.1. Production Field. In the field of production, the value co-creation of online education enterprises is carried out from the perspective of enterprises. From the perspective of supply chain, each end enterprise puts its own type resources and intangible information into the value creation system. Customers put forward value requirements according to their own needs and mix the resources invested by customers so as to integrate the resources of customers and enterprises in the supply chain and cooperate with each other to create business value. This kind of value co-creation can effectively improve the performance and business performance of each enterprise, create a good business image for the enterprise to a certain extent, inject fresh blood into the enterprise, enable the enterprise to continuously create new value, and ensure that a more harmonious relationship can be built between the enterprise and customers. Although under this classification, customers are not the main body of value production, they still play an important role in the process of value co-creation: because customers put forward demands for their own needs, enterprises can make a way conducive to value co-creation according to their needs; as a crucial link in the supply chain, customers also invest their own resources in information interaction, which enriches the level of resources and helps enterprises achieve value creation faster and better; customers and enterprises actively interact with each other to help each other and create business value together [18]. The value co-creation of any commodity in the field of production is dominated by the enterprise, which provides space for customers and takes the enterprise as the leading role. It is necessary to grasp the value creation and production all the time, and at the same time, it is also necessary to improve the level of enterprise management.

4.2.2. Consumption Field. In the field of consumption, if we want to realize the value co-creation, we need to take the customer as the main body, the customer fully considers their own interests, put their own information and knowledge resources into the information interaction, readjust and match the resource information, and use the interactive way to connect the customer and the enterprise so that the resources of the two can be effectively integrated and infiltrated into each other. It is the realization of value co-creation between enterprises and customers. In other words, when customers have demand for goods, enterprises will put forward their own value proposals according to the needs of enterprises. If customers are satisfied with this proposal, they will reach a consensus on value. With the assistance of information interaction, resources can be exchanged, and value co-creation between enterprises and customers can be realized under the supply chain. In order to realize the stable value co-creation, enterprises also need to make support to ensure the realization of value co-creation. It is because of the realization of value co-creation that customers can get good business experience and meet their demand for goods. The main focus of value co-creation under the category of consumption field is the integration of resources between enterprises and customers. Customers take themselves as the main body to create business value, but also need to invest their own resources and make an accurate evaluation of the value created.

The above two kinds of value co-creation classification are from the perspective of different subjects, mainly aiming at the particularity of different subjects to explain co-creation value. Although enterprises and customers have different performance in value pursuit, the demand for value maximization is consistent. Under the information interaction technology, both of them integrate their own information content. However, whether it is production or 
consumption, the pursuit of value co-creation is consistent. Customers and enterprises in the supply chain make their own contributions to the realization of value co-creation.

\section{Case Analysis}

This paper takes an online education enterprise as a case sample to analyze the impact of the company's enterprise development from the perspective of supply chain and the value co-creation business model of school education enterprise under the influence of information interaction technology. Detailed analysis of practical examples is carried out by using the information interaction technology and the basic theory of value co-creation introduced.

5.1. Research Methods and Strategies. There are still many deficiencies in the research of information interaction. In this paper, the research is carried out from the perspective of supply chain. Information interaction technology has the characteristics of organization and strategy. This paper focuses on the analysis of the impact of the use of information interaction technology on the co-creation business model of enterprises. Therefore, specific research is carried out for the enterprises that have made remarkable achievements in the field of online education. This paper analyzes the reasons behind the achievements of the enterprise. In this paper, we believe that information interaction technology can bring high-quality value co-creation effect for enterprises and ensure enterprises to obtain absolute enterprise advantage in similar enterprises. The detailed theoretical framework is as follows:

(1) The resources in the process of information interaction mainly include three aspects: intangible resources, human resource information, and basic information. These three types of information will be generated and applied in the normal business process of enterprises, but not all types of enterprises can be used in general. Online education enterprises use this kind of interactive form to complete information interaction and realize enterprise value co-creation.

(2) In fact, value co-creation is not a specific concept. Generally, related activities are used to carry out this abstract concept, so if it is needed to carry out the research of value co-creation, the perspective of components should be used.

(3) In the process of research, it needs to pay attention to the measurement of enterprise competitiveness. The research dimension includes two aspects, namely, long-term and short-term competitive advantage. The detailed indicators will be studied in the following.

5.2. Case Overview. The example selected in this paper is the enterprise that has achieved considerable results in the current online education enterprise: enterprise A. The enterprise started early for online education, and also, it plays an important leading role in the industry. In this field, the enterprise has been in a leading position. It is precisely because of the excellent business situation of the enterprise the use of information interaction technology can achieve good value and co-create efficiency. The enterprise was founded in 2010 and has developed rapidly in the past decade, which has a great influence in the industry and related industries.

5.3. Data Analysis. The questionnaire survey method is used to collect the data of the online education enterprise, that is, the hypothesis of the impact of information interaction on enterprise value co-creation. The analysis software SPSS 22.0 is used to analyze the data, and the observation variables are set. The content of the scale includes value co-creation, partnership, service concept, and service complexity. On this basis, the reliability and validity of the scale are analyzed, as well as other data. The results are as follows.

5.3.1. Reliability Analysis. The reliability and validity of each scale are evaluated and analyzed. Internal stability, internal consistency and equivalence are the indicators to measure the reliability of waiting room. The purpose of evaluation is to verify the reliability of measurement. In order to avoid the problem of measurement similarity, Cronbach's coefficient $\alpha$ is used to express the degree of homogeneity. 0-1 distribution interval is the value range of Cronbach. $\alpha$-value of $0.64-0.69$ is acceptable; that is, the value is reliable. If $\alpha$ value is $0.69-0.79$, the reliability is moderate. If $\alpha$ value is above 0.79 , the reliability is excellent.

The reliability analysis of information interaction influencing value co-creation is shown in Table 1.

It can be seen from Table 1 that the reliability analysis of the scale of value co-creation shows that each value is above 0.79 . The results of reliability analysis show that the internal consistency of the scale is very high, which indicates that the scale constructed in this paper has good reliability. At the same time, it also shows that information interaction has a positive impact on the business model of value co-creation of online education enterprises.

5.3.2. Validity Analysis. Validity analysis is recognized as a factor to measure the quality of the sample scale in research. The scale used in this study belongs to the high maturity scale, so its validity is acceptable. The composite reliability (greater than 0.69), mean variance (greater than 0.49), and standardized factor (greater than 0.49 ) are used to measure the aggregate validity of the scale. The results of variable factor analysis are shown in Table 2.

It can be seen from Table 2 that the aggregation effect of the scale is good. It can be concluded that each variable factor has reached the specified range, which indicates that the scale constructed in this paper has good reliability. At the same time, it further indicates that information interaction has a positive impact on the value co-creation business model of online education enterprises.

The purpose of data analysis is to verify the impact of information interaction on the value co-creation business 
TABLE 1: Reliability analysis of the scale.

\begin{tabular}{|c|c|c|c|}
\hline Project & Content & $\begin{array}{l}\text { Correlation with the } \\
\text { total score }\end{array}$ & $\begin{array}{l}\text { The coefficient } \\
\text { of } \alpha\end{array}$ \\
\hline \multirow{3}{*}{ Signal communication } & Information exchange between enterprises & 0.855 & \multirow{3}{*}{0.883} \\
\hline & $\begin{array}{l}\text { The upstream enterprises of the supply chain can clearly } \\
\text { understand the opinions of the downstream enterprises }\end{array}$ & 0.848 & \\
\hline & Information exchange between enterprises and customers & 0.842 & \\
\hline \multirow{3}{*}{ To obtain } & Ensure that customers receive detailed product information & 0.851 & \multirow{3}{*}{0.895} \\
\hline & $\begin{array}{l}\text { Customers can obtain the information of commodities } \\
\text { through the Internet and other ways }\end{array}$ & 0.813 & \\
\hline & $\begin{array}{l}\text { Customers are able to accept goods from enterprises along the } \\
\text { supply chain }\end{array}$ & 0.757 & \\
\hline \multirow[t]{2}{*}{ Risk-taking } & $\begin{array}{c}\text { Inform customers of possible risks of the product through } \\
\text { information exchange }\end{array}$ & 0.742 & \multirow[t]{2}{*}{0.831} \\
\hline & The customer shares the risk with the enterprise & 0.817 & \\
\hline \multirow{3}{*}{ Transparency } & $\begin{array}{c}\text { Companies do not use information asymmetry to deceive } \\
\text { customers }\end{array}$ & 0.852 & \multirow{3}{*}{0.831} \\
\hline & $\begin{array}{c}\text { Customers have absolute trust in the enterprise and ensure the } \\
\text { transparency of information between them }\end{array}$ & 0.677 & \\
\hline & $\begin{array}{c}\text { There is no information deception between enterprises and } \\
\text { between enterprises and customers }\end{array}$ & 0.759 & \\
\hline \multirow{3}{*}{$\begin{array}{l}\text { Information interaction } \\
\text { enterprise relationship quality }\end{array}$} & Companies do not harm each other's interests & 0.868 & \multirow{3}{*}{0.889} \\
\hline & Aim to maximize profits & 0.862 & \\
\hline & $\begin{array}{c}\text { Consistent cultural strategies between enterprises and between } \\
\text { enterprises and customers }\end{array}$ & 0.839 & \\
\hline \multirow{3}{*}{$\begin{array}{l}\text { Cooperative innovation } \\
\text { performance }\end{array}$} & Improve product quality through innovation & 0.813 & \multirow{3}{*}{0.855} \\
\hline & Accelerate the commercialization of goods & 0.788 & \\
\hline & Businesses make profits from the sale of goods & 0.818 & \\
\hline
\end{tabular}

TABLE 2: Variable factor analysis.

\begin{tabular}{|c|c|c|c|c|c|}
\hline Project & Content & $\begin{array}{c}\text { Normalized factor } \\
\text { coefficient }\end{array}$ & $\begin{array}{l}\text { The } \\
\text { mean }\end{array}$ & $\begin{array}{c}\text { The standard } \\
\text { deviation }\end{array}$ & $\begin{array}{c}T- \\
\text { statistic }\end{array}$ \\
\hline \multirow{3}{*}{ Signal communication } & Information exchange between enterprises & 0.853 & 0.858 & 0.044 & 25.719 \\
\hline & $\begin{array}{c}\text { The upstream enterprises of the supply chain can } \\
\text { clearly understand the opinions of the downstream } \\
\text { enterprises }\end{array}$ & 0.848 & 0.851 & 0.053 & 19.881 \\
\hline & $\begin{array}{c}\text { Information exchange between enterprises and } \\
\text { customers }\end{array}$ & 0.864 & 0.866 & 0.045 & 24.894 \\
\hline \multirow{3}{*}{ To obtain } & $\begin{array}{c}\text { Ensure that customers receive detailed product } \\
\text { information }\end{array}$ & 0.869 & 0.869 & 0.042 & 27.582 \\
\hline & $\begin{array}{l}\text { Customers can obtain the information of } \\
\text { commodities through the Internet and other ways }\end{array}$ & 0.888 & 0.881 & 0.042 & 28.888 \\
\hline & $\begin{array}{l}\text { Customers are able to accept goods from } \\
\text { enterprises along the supply chain }\end{array}$ & 0.918 & 0.918 & 0.028 & 47.677 \\
\hline \multirow[t]{2}{*}{ Risk-taking } & $\begin{array}{l}\text { Inform customers of possible risks of the product } \\
\text { through information exchange }\end{array}$ & 0.865 & 0.867 & 0.031 & 28.584 \\
\hline & The customer shares the risk with the enterprise & 0.898 & 0.898 & 0.035 & 36.748 \\
\hline \multirow{3}{*}{ Transparency } & $\begin{array}{c}\text { Companies do not use information asymmetry to } \\
\text { deceive customers }\end{array}$ & 0.784 & 0.798 & 0.076 & 12.273 \\
\hline & $\begin{array}{l}\text { Customers have absolute trust in the enterprise and } \\
\text { ensure the transparency of information between } \\
\text { them }\end{array}$ & 0.923 & 0.921 & 0.038 & 34.113 \\
\hline & False information of all units & 0.886 & 0.887 & 0.039 & 30.862 \\
\hline \multirow{3}{*}{$\begin{array}{l}\text { Information interaction } \\
\text { enterprise relationship } \\
\text { quality }\end{array}$} & Companies do not harm each other's interests & 0.828 & 0.3827 & 0.045 & 24.331 \\
\hline & Aim to maximize profits & 0.789 & 0.789 & 0.059 & 16.599 \\
\hline & $\begin{array}{l}\text { Consistent cultural strategies between enterprises } \\
\text { and between enterprises and customers }\end{array}$ & 0.821 & 0.821 & 0.054 & 19.118 \\
\hline \multirow{3}{*}{$\begin{array}{l}\text { Cooperative innovation } \\
\text { performance }\end{array}$} & Improve product quality & 0.812 & 0.763 & 0.085 & 12.342 \\
\hline & Accelerate the commercialization of goods & 0.873 & 0.866 & 0.052 & 21.158 \\
\hline & Product revenue & 0.811 & 0.788 & 0.054 & 18.932 \\
\hline
\end{tabular}


TABLE 3: Comparison of information interaction behavior and value co-creation.

\begin{tabular}{|c|c|c|}
\hline Compare the content of & To create value & Information interaction \\
\hline The initial stage & The general needs of customers and enterprises are met & There is information distortion \\
\hline Prerequisite for & Transparency, communication, and risk-taking & $\begin{array}{c}\text { Information interaction infrastructure, information } \\
\text { interaction resources }\end{array}$ \\
\hline Process & $\begin{array}{c}\text { Enterprise value co-creation management, } \\
\text { interactive experience }\end{array}$ & Content optimization \\
\hline The results of & $\begin{array}{l}\text { Both the enterprise and the customer achieve } \\
\text { a high-quality experience }\end{array}$ & Effective and high-level presentation of information \\
\hline
\end{tabular}

model of online education enterprises from the perspective of supply chain. Through the above data analysis, this paper obtains the verification results through a series of analysis methods such as questionnaire survey, proving that information interaction has a positive impact on enterprise's value co-creation.

From the perspective of supply chain interpretation, online education enterprises use information interaction in many aspects to achieve value co-creation between enterprises and between enterprises and similar enterprises. Table 3 shows the comparative analysis results of the two.

From the perspective of supply chain, online education enterprises use information interaction to continuously optimize and improve the content, reduce the possibility of information distortion, enhance the value of information interaction, effectively realize enterprise's value co-creation, meet the needs of enterprise development, ensure the consistency of production information and enterprise production information, and reduce the information gap between enterprises and customers caused by poor communication.

\section{Conclusion}

This paper analyzes the impact of information interaction ability on the value co-creation business model of online education enterprises from the perspective of supply chain. Through the research, the following conclusions can be obtained:

(1) For the scale of value co-creation, the reliability analysis is carried out, and each $\alpha$ value reaches more than 0.79 . The reliability analysis results show that the internal consistency of the scale is very high, which shows that the reliability of the scale constructed in this paper is good. At the same time, it also shows that information interaction has a positive impact on the value co-creation business model of online education enterprises.

(2) The verification results are obtained by a series of analysis means, such as questionnaire survey. The data analysis results show that information interaction has a positive impact on the value co-creation business model of online education enterprises.

(3) From the perspective of supply chain, online education enterprises continuously optimize and improve the content when using information interaction, reduce the possibility of information distortion, enhance the value of information interaction, effectively realize enterprise value co-creation, meet the needs of enterprise development, ensure the consistency between production information and enterprise production information, and reduce the information gap between enterprises and customers caused by poor communication.

\section{Data Availability}

The datasets used and/or analyzed during the current study are available from the corresponding author on reasonable request.

\section{Conflicts of Interest}

The authors declare no potential conflicts of interest with respect to the research, authorship, and/or publication of this article.

\section{Acknowledgments}

This study was supported by The impact of information interaction ability on value co-creation business model from the perspective of supply chain-based on the competitiveness of online education enterprises, General Social Science Project of Guangdong Department of Education (230419073).

\section{References}

[1] J. Zhang, K. Schmidt, H. Xie, and H. Li, "A new mixed approach for modelling and assessing environmental influences to value co-creation in the construction industry," International Journal of Production Research, vol. 54, no. 21, pp. 6548-6562, 2018.

[2] M. Rafiei and L. A. R. Sandoval, "New frontiers, challenges, and opportunities in integration of design and control for enterprise-wide sustainability," Computers \& Chemical Engineering, vol. 132, no. 4, pp. 106610.1-106610.18, 2020.

[3] C. Wang, Z. Wang, R.-Y. Ke, and J. Wang, "Integrated impact of the carbon quota constraints on enterprises within supply chain: direct cost and indirect cost," Renewable and Sustainable Energy Reviews, vol. 92, no. 9, pp. 774-783, 2018.

[4] T.-M. Choi, Y.-J. Cai, and B. Shen, "Sustainable fashion supply chain management: a system of systems analysis," IEEE Transactions on Engineering Management, vol. 66, no. 4, pp. 730-745, 2019.

[5] R. B. Gonzalo, O. M. Hurtado, C. Lunerti et al., "Biometric systems interaction assessment: the state of the art," IEEE 
Transactions on Human-Machine Systems, vol. 49, no. 5, pp. 397-410, 2019.

[6] D. Priharsari, B. Abedin, and E. Mastio, "Value co-creation in firm sponsored online communities," Internet Research, vol. 30, no. 3, pp. 763-788, 2020.

[7] Y. Ma, K. Rong, Y. Luo, Y. Wang, D. Mangalagiu, and T. F. Thornton, "Value co-creation for sustainable consumption and production in the sharing economy in China," Journal of Cleaner Production, vol. 208, no. 16, pp. 1148-1158, 2019.

[8] L. Li, Q. Huang, K. Yeung, and Z. Jian, "Human-computer interaction and value co-creation in electronic service," Industrial Management \& Data Systems, vol. 118, no. 1, pp. 218-235, 2018.

[9] L. Lei, T. Chi, T. Hao, and Y. Tao, "Customer demand analysis of the electronic commerce supply chain using big data," Annals of Operations Research, vol. 268, no. 1-2, pp. 113-128, 2018.

[10] H. Zhang, S. Gupta, W. Sun, and Y. Zou, "How social-mediaenabled co-creation between customers and the firm drives business value? the perspective of organizational learning and social capital," Information \& Management, vol. 57, no. 3, Article ID 103200, 2019.

[11] Y. Zhao, Y. Chen, R. Zhou, and Y. Ci, "Factors influencing customers' willingness to participate in virtual brand community's value co-creation: the moderating effect of customer involvement," Online Information Review, vol. 43, no. 3, pp. 440-461, 2018.

[12] Z. P. Dong, Q. G. Xu, and L. Ren, "Simulation of supply chain equilibrium optimization management in multi-layer logistics storage facilities," Computer Simulation, vol. 35, no. 3, pp. 361-364, 2018.

[13] B. Partida, "Sales order automation benefits the supply chain," Logistics Management, vol. 57, no. 9, pp. 22-24, 2018.

[14] H. K. Chan, J. Griffin, J. J. Lim, F. Zeng, and A. S. F. Chiu, "The impact of $3 \mathrm{~d}$ printing technology on the supply chain: manufacturing and legal perspectives," International Journal of Production Economics, vol. 205, no. 11, pp. 156-162, 2018.

[15] Adrienne and Selko, "Why can't the supply chain get rid of abuse," Material Handling \& Logistics, vol. 73, no. 1, p. 32, 2018.

[16] M. Hamelink and R. Opdenakker, "How business model innovation affects firm performance in the energy storage market," Renewable Energy, vol. 131, no. 2, pp. 120-127, 2019.

[17] M. Langenus and M. Dooms, "Creating an industry-level business model for sustainability: the case of the european ports industry," Journal of Cleaner Production, vol. 195, pp. 949-962, 2018.

[18] P. Lloyd and A. Oak, "Cracking open co-creation: categories, stories, and value tension in a collaborative design process," Design Studies, vol. 57, no. 7, pp. 93-111, 2018. 